\title{
Purchase Behaviour of Rural Customers in Insurance Sector
}

\section{OPEN ACCESS}

Volume: 6

Issue: 4

Month: April

Year: 2019

ISSN: 2321-4643

Received: 15.03.2019

Accepted: 30.03.2019

Published: 01.04.2019

Citation:

Rajasri, T., and K. Gomathi

Shankar. "Purchase Behaviour of Rural Customers in Insurance Sector." Shanlax International Journal of Management, vol. 6, no. 4, 2019, pp. 13-17.

DOI:

https://doi.org/10.34293/ management.v6i4.347

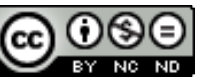

This work is licensed under a Creative Commons Attribution-NonCommercialNoDerivatives 4.0 International License

\section{T.Rajasri}

Ph.D., (Full Time) Research Scholar, Department of Business Administration Annamalai University, Chidambaram, Tamil Nadu, India

\section{K.Gomathi Shankar}

Assistant Professor, Department of Business Administration

Annamalai University, Chidambaram, Tamil Nadu, India

\begin{abstract}
Human life is full of risk. In general one or few family members are earning to run the existence, and most of the family members are depending on the earning members. In the present world, a human may lose his life by many ways such as, by age, by accident, by diseases and so on no one compensate by anybody else. One can succeed an insurance company only when it retain their existing customers and attract new customers by providing good insurance services. For this purpose understanding of purchase behaviour of customers in the insurance sector is very important to improve the quality of existing schemes and to introduce new schemes in insurance products to attract new customers and it will lead to enhancing their market. Tamilnadu is one of the biggest states in India. There are 32 districts in the state of Tamilnadu, among them Cuddalore district is one of the important districts, since the number of villages is more in the region and most of them depend on agriculture for their livelihood. Awareness about insurance policies among rural people is lower than people in urban areas. The researcher will specifically consider life insurance products in the insurance sector. Hence the researcher has intended to assess the awareness level of rural people in the study area on various aspects of life insurance products. The researcher will analyse the purchase behaviour of rural people in the study area towards life insurance products.
\end{abstract}

Keywords: Purchase behaviour, Insurance sector, Insurance policies, urban areas, rural people, and Insurance products.

\section{Introduction}

India is a country where the average selling of insurance policies is still lower than in many western and Asian countries. With the second largest population in the world, the Indian insurance market is looking very prospective to many multinational and Indian insurance companies for expanding their business and market share. Before the opening of the Indian market for Multinational Insurance Companies, Life Insurance Corporation (LIC) was the only company which distributed with Insurance and after the commencing of this sector to other private companies, all the world leaders of life insurance have started their operation in India. With their world market experience and network, these concerns have offered many decent schemes to lure all type of Indian consumers but unfortunately failed to get the crucial share of market. Still, the Insurance Corporation is the massive player in the insurance market with approx. $65 \%$ market share in India. Indian consumers do not trust many companies, and the key population of India do not has any insurance policy, the factors play a main role in buying behaviour of consumers towards insurance policies in India. 
Rural insurance in India has assumed significance in the recent past with the growth of the Indian economy. Further income and employment chances in rural areas have increased the purchasing power of rural consumers. Rural reach is on the rise, and it is fast becoming the most important route to growth for the Industry. New approaches, new strategic alternatives and new operational techniques are being evolved to gain competitive advantage.

\section{Statement of the Problem}

Insurance sector is playing a pivotal role in reducing risk economically for both human lives through life insurance and other assets through general insurance. Among them life insurance is very dominant, since it helps a human in two ways, firstly through investment and offering the considerable yearly return on investment, then it helps through reducing the risk of human life economically. Until a few decades ago, there was a low level of awareness about life insurance among people even the urban area, but still, the level of consciousness is low among rural people. The growth of investments in assurance in rural areas is very small in India. Investments in life insurance vary based on the demographical and economic background of rural people. Hence the researcher has proposed to study a demographical and economic circumstantial of the respondents. Investment in life insurance is influenced by the level of awareness among people, therefore this aspect is also suggested to include in the study. The researcher also has suggested studying the characteristics of purchase behaviour of the respondents towards life insurance products in the study area and the level of satisfaction among the respondents on various features of life insurance products in the study area.

\section{Objectives of the Study}

1. To assess awareness among respondents about life insurance policies in the study area

2. To study the purchase behaviour of the respondents towards life insurance policies in the study area

\section{Review of Literature}

In the competitive world, purchaser satisfaction is the most significant aspect to every company which hold buyer to raise and to continue as a satisfied customer is the supreme trademark representative to concentration the potential customers to the company. The above proverb is exact, particularly in the service sector like insurance. In rural insurance sector, after denationalisation, many new private companies have entered the industry by merging with foreign companies. Apart from this, there exist other factors which also lead to the purchase behaviour of rural customers in the insurance sector. The researcher will review earlier studies in the same line, from various journals, magazines, newspapers, internet sources, books, theses, reports and so on. The researcher will present his view appropriately.

\section{Research Methodology}

Tamilnadu is one of the biggest states in India and occupying 6th place in terms of population. The state also has many numbers of villages. The district of Cuddalore is one of the most backward region in the state of Tamilnadu. In 2006 the Ministry of Panchayati Raj is a branch of the Government of India looking after the on-going process of decentralisation and local governance in the States. The Cuddalore domain one of the country's 250 most backward region (out of a total of 640). It is one of the six districts in Tamil Nadu currently receiving funds from the Backward Regions Grant Fund Programme (BRGF). One-third of the total populations are living in rural areas of the district. Hence the researcher has selected the district a study area. The researcher has planned to collect primary data from 520 respondents in the study area using a random sampling method through well-structured interview schedule. The researcher has proposed to apply statistical tools such as mean, standard deviation, co-efficient of correlation, Chi-square test, ' $t$ ' test and ANOVA.

Table: 1 Gender- Wise Purchase Behaviour in Insurance Policy by Rural Customers

\begin{tabular}{|l|c|c|}
\hline \multicolumn{1}{|c|}{ Gender } & Frequency & Per cent \\
\hline Male & 335 & 64.4 \\
\hline Female & 185 & 35.6 \\
\hline Total & $\mathbf{5 2 0}$ & $\mathbf{1 0 0 . 0}$ \\
\hline
\end{tabular}

Source: Primary data 
From the above table, $64.4 \%$ of male respondents have purchased insurance policies during the period, and $35.6 \%$ of the respondents are obtained insurance policies during the year. Therefore the researcher concluded that majority of the male respondents have acquired behaviour in rural respondents compared with female respondents.

\section{Table: 2 Age-Wise Purchase Behaviour in Insurance Policy by Rural Customers}

\begin{tabular}{|l|c|c|}
\hline \multicolumn{1}{|c|}{ Age } & Frequency & Percent \\
\hline Below 20 years & 35 & 6.7 \\
\hline $21-40$ years & 165 & 31.7 \\
\hline $41-60$ years & 265 & 51.0 \\
\hline
\end{tabular}

\begin{tabular}{|c|c|c|}
\hline Above 60 years & 55 & 10.6 \\
\hline Total & $\mathbf{5 2 0}$ & $\mathbf{1 0 0 . 0}$ \\
\hline
\end{tabular}

Source: Primary data

From the above table mentioned that $6.7 \%$ of the below 20 year aged people purchased insurance policies during the period, $31.7 \%$ of the $21-40$ year old respondents bought insurance policies, 51\% of the 41-60 year old respondents are purchased insurance policies during the study period and $10.6 \%$ of the above 60years of respondents had purchase insurance policies during the study period. Hence the researcher concluded that the majority of the $51 \%$ of the 41-61 years of aged people purchase insurance policies other than respondents.

Table: 3 ' $t$ ' test for Significance Different between Gender and Concept of Insurance

\begin{tabular}{|c|c|c|c|c|c|c|}
\hline \multirow{3}{*}{ Purpose of insurance } & \multicolumn{4}{|c|}{ Gender } & \multirow{3}{*}{ 't' value } & \multirow{3}{*}{ 'P' value } \\
\hline & \multicolumn{2}{|c|}{ Male } & \multicolumn{2}{|c|}{ Female } & & \\
\hline & Mean & SD & Mean & SD & & \\
\hline Prevent certain events & 17.22 & 4.53 & 15.57 & 4.92 & 3.40 & 0.001 \\
\hline Prevent damage to assets from certain events & 17.60 & 4.20 & 16.67 & 3.52 & 2.329 & 0.021 \\
\hline Re- build the asset lost due to certain events & 17.07 & 4.61 & 16.08 & 4.14 & 2.332 & 0.020 \\
\hline Compensate for loss of life & 16.99 & 4.75 & 16.03 & 4.52 & 2.089 & 0.038 \\
\hline
\end{tabular}

Source: Primary data.

Since P-value is less than 0.01 , the null hypothesis is rejected at $1 \%$ level with regard to prevent certain events. Hence there is a significant difference between male and female of policy holders about who took policy for the purpose to check certain measures during the purpose. Based on mean score female respondents are better in the purpose of

insurance than male in all respects because female respondents were having close contact with their wards than male at home. Hence the researcher concluded that both male and female respondents are interested in taking insurance policy during the condition. Male respondents are popular of insurance policies compare to female respondents.

Table: 4 ANOVA for Significance Difference between

Age Group in Years with concerning of Insurance

\begin{tabular}{|c|c|c|c|c|c|c|}
\hline \multirow{2}{*}{ Purpose of insurance } & \multicolumn{4}{|c|}{ Age (in years) } & \multirow{2}{*}{ 'F' value } & \multirow{2}{*}{ P-value } \\
\hline & Below 20 & $21-40$ & $41-60$ & Above 60 & & \\
\hline Prevent certain events & $\begin{array}{l}16.21^{\mathrm{a}} \\
(4.91)\end{array}$ & $\begin{array}{l}16.27^{\mathrm{a}} \\
(4.16)\end{array}$ & $\begin{array}{l}18.42^{\mathrm{b}} \\
(5.03)\end{array}$ & $\begin{array}{l}16.62^{\mathrm{a}} \\
(4.21)\end{array}$ & 6.516 & $<0.001 * *$ \\
\hline $\begin{array}{l}\text { Prevent damage to assets } \\
\text { from certain events }\end{array}$ & $\begin{array}{l}17.21^{\mathrm{a}} \\
(3.86)\end{array}$ & $\begin{array}{l}16.92^{\mathrm{a}} \\
(3.73)\end{array}$ & $\begin{array}{l}18.61^{\mathrm{b}} \\
(4.62)\end{array}$ & $\begin{array}{l}16.84^{\mathrm{a}} \\
(3.87)\end{array}$ & 4.989 & $<0.001 * *$ \\
\hline $\begin{array}{l}\text { Destroyed the assets from } \\
\text { certain events }\end{array}$ & $\begin{array}{l}16.63^{\mathrm{a}} \\
(4.23)\end{array}$ & $\begin{array}{l}16.06^{\mathrm{a}} \\
(4.23)\end{array}$ & $\begin{array}{l}18.27^{\mathrm{b}} \\
(4.04)\end{array}$ & $\begin{array}{l}16.64^{\mathrm{a}} \\
(4.33)\end{array}$ & 6.002 & $<0.000 * *$ \\
\hline Compensate for loss of life & $\begin{array}{l}16.56^{\mathrm{a}} \\
(4.46)\end{array}$ & $\begin{array}{l}16.18^{\mathrm{a}} \\
(4.33)\end{array}$ & $\begin{array}{l}17.95^{\mathrm{b}} \\
(5.54)\end{array}$ & $\begin{array}{l}16.51^{\mathrm{a}} \\
(4.32)\end{array}$ & 3.615 & $0.013^{*}$ \\
\hline
\end{tabular}

Note: 1 . the value within bracket refers to $\mathrm{SD}, 2 . * *$ denotes significant at $1 \%$ level,

3.* denotes significant at $5 \%$ level 
Since P-value is less than 0.01 , the null hypothesis rejects at $1 \%$ level about the purpose of avoid certain events and prevent damage to assets from certain happenings. Hence there is a significant difference between age group in years about the aim of preventing certain occasions, avert damage to assets from certain procedures and destroyed the asset lost due to certain dealings. Based on Duncan Multiple Range Test(DMRT) up to 41-60 years of age is significantly differed with below 20 years,21-40 years and above 60 years of age people at $1 \%$ level of significance, but there is no significant difference between up to the age of below 20 years, $21-40$ years and above 60 years respectively.

Since P-value is less than 0.05 , the null hypothesis is rejected at $5 \%$ level about compensate for loss of life. Hence there is a significant difference among purpose of insurance with regard to compensate for the loss of life. Based on Duncan Multiple Range Test (DMRT) 41-60 years of age respondents were significantly differed with, below 20 years of age, 21-40 years of age and above 60 years of age respectively. Hence the researcher found that 41-60 years of age respondents have a purpose of taking an insurance policy to prevent certain events during the era.

\section{Important Findings}

- Majority of the male respondents were having purchase behaviour in rural respondents compared with female respondents.

- Compare to another respondent those who are belonging age group of 41-61 purchased more insurance policy.

- The study found that both male and female respondents are interested to take insurance policy during the period; male respondents are the majority to extract the insurance policies other than female.

- Based on Duncan Multiple Range Test (DMRT) 41-60 years of age respondents were significantly differed with below 20 years of age, 21-40 years of age and above 60 years of age respectively. Hence the researcher found that 41-60 years of age respondents were having the purpose of insurance policy for necessary to take prevent certain events during period.

\section{Conclusion}

Now a day insurance companies are successfully running their business, the majority of the peoples are getting an insurance policy to run a smooth life. In rural customer's awareness about insurance policy like life insurance, general insurance, health insurance and accidental insurance, through the advertisement, LIC agent and relatives etc. Some of the people are not aware of the insurance policy because of lack of education and lack of money due to seasonal unemployment and failure of monsoon. The present study found that the majority of the rural customers are purchasing insurance policy during the last decade, some of the people are not aware about the insurance, so that the insurance companies have to take necessary steps like, to conduct insurance camps, insurance awareness programmes and to improve the insurance companies as well as improve the life of rural customers in future.

\section{References}

Ahmed, A., \& Kwatra, N., "Level of Customers Satisfaction with their Perception on the Quality of Insurance Services", Galaxy International Interdisciplinary Research Journal, vol. 2, no. 3, 2014, pp. 188-193. http://internationaljournals. co.in/pdf/GIIRJ/2014/March/19.pdf.

Ahmed, "Perception of Life Insurance Policies in rural India", Kuwait Chapter of Arabian Journal of Business and Management Review, vol. 2, no. 6, 2013, pp. 17-24. https://www.arabianjbmr. com/pdfs/KD_VOL_2_6/3.pdf.

Annamalah, S., "Profiling and Purchasing Decision of Life Insurance Policies among Married Couples in Malaysia," World Applied Sciences Journal, vol. 23, no. 3, 2011, pp.296-304.

https://pdfs.semanticscholar. org/0cd6/675cfa44ef24064cbad857a43 9660cc79f86.pdf.

Arul Suresh, "Empirical Study on Satisfaction of the Policyholders towards the Services Provided by LIC of India in Madurai Division," International Journal of Multidisciplinary Research, vol. 1, no. 8, 2011, pp. 552-557. http://docshare02. docshare.tips/files/17086/170866279.pdf. 
Prakash,"Consumer Awareness of HDFC Standard in Life Insurance Company Limited," Research Journal of Commerce and Behavioural Science. vol.1, no. 11, 2012, pp. 36-45.

http://www.theinternationaljournal.org/ojs/ index.php?journal $=$ rjcbs \&page $=$ article \&op $=$ view\&path $\% 5 \mathrm{~B} \% 5 \mathrm{D}=1220$

Rajeswari., \& Kartheeswari, "Perception of customers towards Life Insurance Services," Sri Krishna International Research \& Educational Consortium. vol. 2, no. 12, 2011, pp. 1-15. https://wwjournals.com/index.php/gjra/article/ view/9514.

Rajkumar, A.M., \& Kannan, N., “A study on customer satisfaction of life insurance policies with special reference to max New York life insurance, Chennai," International Journal of Financial Management Research and Development, vol. 1, no. 1, 2011, pp. 36-60.

https://www.slideshare.net/Annamumumu/astudy-on-customer-satisfaction-of-lifeinsurance-policies

\section{Author Details}

T.Rajasri, Ph.D., (Full Time) Research Scholar, Department of Business Administration, Annamalai University, Chidambaram, Tamil Nadu, India, Email ID: rajib.com007@gmail.com.

Dr.K.Gomathi Shankar, Assistant Professor, Department of Business Administration, Annamalai University, Chidambaram, Tamil Nadu, India. 